\title{
Experimental studies on fiber reinforced concrete
}

\author{
Utkarsh R.Nishane ${ }^{1}$, Nitin U. Thakare ${ }^{2}$ \\ ${ }^{l}$ (Research Scholar, Department of civil Engineering, G.H. RAISONI POLYTECHNIC, NAGPUR \\ ${ }^{2}$ (HOD, Department of civil Engineering, G.H. RAISONI POLYTECHNIC, NAGPUR
}

\begin{abstract}
The concepts of using fibres in order to reinforce matrices weak in tension is more than 4500 years old.since Portland cement concrete started to be used widely as a construction material attempts were made to use fibres for arresting cracks enhance the strength etc. The development of fibre reinforcement for concrete was very slow before 1960 's. Fibers are generally used as resistance of cracking and strengthening of concrete. In this project we are going to compare the compressive strength of 3,7 and 28 days of aramid fibres to the ordinary concrete and fibre reinforced concrete i.e. glass fibres and steel fibres. The concrete is design for M20 grade of concrete. According to various research papers, it has been found that steel fibers give the maximum strength in comparison and glass fibre is used for crack resistance but aramid simultaneously gives strength and can be used for crack resistance. Now a days there exists many reinforcement techniques for improving the strength of those materials which lacks load carrying and less durable capacity. Fiber reinforced concrete has been successfully used in slabs on grade, shotcrete, architectural panels, precast products, offshore structures, structures in seismic regions, thin and thick repairs, crash barriers, footings, hydraulic structures and many other applications. This review study is a trial of giving some highlights for inclusion of aramid fibers especially in terms of using them with new types of concrete.

Keywords: Compressive strength, ductility, flexural strength, aramid fibres, Fibre Reinforced Concrete, Split tensile strength, toughness, workability.
\end{abstract}

\section{INTRODUCTION}

Application of Fibre Reinforced Concrete (FRC) is continuously growing in various application fields. FRC is widely used in structures. Due to the property that fibre enhances toughness of concrete, FRC is used on large scale for structural purposes. The fibre is described by a convenient parameter called aspect ratio. The aspect ratio of the fiber is the ratio of its length to its diameter. The principle motive behind incorporating fibers into a cement matrix is to increase the toughness and tensile strength and improve the cracking deformation characteristics of the resultant composite. For FRC to be a valuable construction material, it must be able to compete economically with existing reinforcing system. FRC composite properties, such as crack resistance, reinforcement and increase in toughness are dependent on the mechanical properties of the fiber, bonding properties of the fiber and matrix, as well as the quantity and distribution within the matrix of the fibers. It improves fatigue resistance makes crack pattern distributed. By making crack pattern distributed, it is meant that it decreases the crack width. Aramid fibre gives more compressive strength and crack resistance to concrete as compare to glass and steel fibre.

\section{MATERIALS}

\begin{tabular}{|cl|l|}
\hline i. & Cement & $\begin{array}{l}\text { Pozzolana } \\
\text { cement of [53 grade] }\end{array}$ \\
\hline ii. & $\begin{array}{l}\text { Coarse } \\
\text { aggregate }\end{array}$ & Size $20 \mathrm{~mm}$ \\
\hline iii. & Fine aggregate & Size $10 \mathrm{~mm}$ \\
\hline iv. & Sand & Less than $4.75 \mathrm{~mm}$ \\
\hline v. & Admixture & Super plasticizers \\
\hline vi. & Fibres & $\begin{array}{l}\text { Glass fibre, steel fibre } \\
\text { and Aramid fibre. }\end{array}$ \\
\hline vii. & Water & Potable water \\
\hline
\end{tabular}

\section{METHODOLOGY}

Concrete ingredients are firstly collected from various locations. As per IS specification material is tested i.e. test which are usually performed to check the material's physical properties. The proportioning of quantity of cement, materials like fine aggregate, coarse aggregate and fibres like Glass fibre, Steel fiber and Aramid fibre has been done by weight as per the mix design . Water, super plasticizer were measured by volume. Concrete was design for M20 grade as per IS 4562000 and IS 10262.

The mixing process is carried out in concrete mixture. The materials are laid in uniform layers, one on the other in order - fine aggregate, coarse aggregate and fibres as per the percentage like $0.3 \%, 0.5 \%$ and $0.7 \%$ respectively. Dry mixing 
Is done, then cement is added and in last water is added. Fresh concrete is tested to check the slump of concrete, as addition of different percentage of fibres may change the slump of concrete, then concrete is

\section{RESULT}

Results for M-20 Grade of Concrete in Compression Test of 3, 7 And 28 Days filled in empty moulds and kept for 24 hours. After 24 hours cubes are de-mould and placed in curing tank for curing. After that compressive testing was done after 3,7 , and 28 days of curing.

ORDINARY CONCRETE

\begin{tabular}{|l|l|l|l|}
\hline \multicolumn{4}{|l|}{ M20 PCC } \\
\hline BLOCK & LOAD(KN) & LOAD(KG) & STRESS=LOAD/AREA \\
\hline 3 days & 176 & 17600 & 7.82 N/SQ.MM \\
\hline 7 days & 292 & 29200 & 12.98 N/SQ.MM \\
\hline 28 days & 492 & 49200 & 21.87 N/SQ.MM \\
\hline
\end{tabular}

Table no.1

GLASS FIBER

\begin{tabular}{|l|l|l|l|}
\hline \multicolumn{4}{|l|}{ M $20[0.3 \%]$} \\
\hline BLOCK & LOAD(KN) & LOAD $(\mathrm{KG})$ & STRESS=LOAD/AREA \\
\hline 3 days & 188 & 18800 & 8.35 N/SQ.MM \\
\hline 7 days & 279 & 27900 & 12.4 N/SQ.MM \\
\hline 28 days & 496 & 49600 & 22.04 N/SQ.MM \\
\hline
\end{tabular}

Table no. 2

\begin{tabular}{|l|l|l|l|}
\hline \multicolumn{4}{|l|}{ M $20[0.5 \%]$} \\
\hline BLOCK & LOAD $(\mathrm{KN})$ & LOAD $(\mathrm{KG})$ & STRESS=LOAD/AREA \\
\hline 3 days & 227 & 22700 & 10.08 N/SQ.MM \\
\hline 7 days & 269 & 26900 & 11.95 N/SQ.MM \\
\hline 28 days & 630 & 63000 & 28.00 N/SQ.MM \\
\hline
\end{tabular}

Table no. 3

\begin{tabular}{|l|l|l|l|}
\hline \multicolumn{4}{|l|}{ M $20[0.7 \%]$} \\
\hline BLOCK & LOAD $(\mathrm{KN})$ & LOAD $(\mathrm{KG})$ & STRESS=LOAD/AREA \\
\hline 3 days & 198 & 19800 & 8.8 N/SQ.MM \\
\hline 7 days & 337 & 33700 & 14.98 N/SQ.MM \\
\hline 28 days & 652 & 65200 & 28.98 N/SQ.MM \\
\hline
\end{tabular}

Table no.4

STEEL FIBER

\begin{tabular}{|l|l|l|l|}
\hline \multicolumn{4}{|c|}{ M $20[0.3 \%]$} \\
\hline BLOCK & LOAD $(\mathrm{KN})$ & LOAD $(\mathrm{KG})$ & STRESS=LOAD/AREA \\
\hline 3 days & 283 & 28300 & 12.57 N/SQ.MM \\
\hline 7 days & 343 & 34300 & 15.24 N/SQ.MM \\
\hline 28 days & 630 & 63000 & 23.24 N/SQ.MM \\
\hline
\end{tabular}

Table no.5

\begin{tabular}{|l|l|l|l|}
\hline \multicolumn{4}{|l|}{$20[0.5 \%]$} \\
\hline BLOCK & LOAD $(\mathrm{KN})$ & LOAD $(\mathrm{KG})$ & STRESS=LOAD/AREA \\
\hline 3 days & 300 & 30000 & 13.33 N/SQ.MM \\
\hline 7 days & 373 & 37300 & 16.57 N/SQ.MM \\
\hline 28 days & 521 & 52100 & 24.31 N/SQ.MM \\
\hline
\end{tabular}

Table no.6 

ISSN : 2248-9622, Vol. 7, Issue 5, ( Part-2) May 2017, pp.40-44

\begin{tabular}{|l|l|l|l|}
\hline \multicolumn{4}{|l|}{ M $20[0.7 \%]$} \\
\hline BLOCK & LOAD $(\mathrm{KN})$ & LOAD $(\mathrm{KG})$ & STRESS=LOAD/AREA \\
\hline 3 days & 312 & 31200 & 13.87 N/SQ.MM \\
\hline 7 days & 364 & 36400 & 16.17 N/SQ.MM \\
\hline 28 days & 624 & 62400 & 27.73 N/SQ.MM \\
\hline
\end{tabular}

Table no.7

\begin{tabular}{|c|c|c|c|}
\hline \multicolumn{4}{|c|}{ ARMID FIBER } \\
\hline M 20[0 & \% ] & & \\
\hline BLOCK & $\mathrm{LOAD}(\mathrm{KN})$ & LOAD $(\mathrm{KG})$ & STRESS $=$ LOAD/AREA \\
\hline 3 days & 543 & 54300 & 24.13 N/SQ.MM \\
\hline 7 days & 573 & 57300 & 25.67 N/SQ.MM \\
\hline 28 days & 660 & 66000 & 29.33 N/SQ.MM \\
\hline
\end{tabular}

\begin{tabular}{|l|l|l|l|}
\hline \multicolumn{3}{|l|}{ M $20[0.5 \%]$} \\
\hline BLOCK & LOAD $(\mathrm{KN})$ & LOAD $(\mathrm{KG})$ & STRESS=LOAD/AREA \\
\hline 3 days & 564 & 56400 & 25.07 N/SQ.MM \\
\hline 7 days & 700 & 70000 & 31.11 N/SQ.MM \\
\hline 28 days & 847 & 84700 & 37.64 N/SQ.MM \\
\hline
\end{tabular}

Table no.9

\begin{tabular}{|l|l|l|l|}
\hline \multicolumn{4}{|l|}{ M $20[0.7 \%]$} \\
\hline BLOCK & LOAD $(\mathrm{KN})$ & LOAD $(\mathrm{KG})$ & STRESS=LOAD/AREA \\
\hline 3 days & 562 & 56200 & 24.98 N/SQ.MM \\
\hline 7 days & 686 & 68600 & 30.49 N/SQ.MM \\
\hline 28 days & 692 & 69200 & 30.75 N/SQ.MM \\
\hline
\end{tabular}

Table no.10

Comparison between Aramid fibre to Glass fibre and steel fibre on basis of Percentage increased in strength of 28 days

\begin{tabular}{|l|l|l|l|l|}
\hline Grade of concrete & $\%$ of fibre & Aramid fibre & Glass fibre & $\%$ of increased \\
\hline & & $\begin{array}{l}\text { Stress } \\
\text { (N/SQ.MM) }\end{array}$ & $\begin{array}{l}\text { Stress } \\
\text { (N/SQ.MM) }\end{array}$ & \\
\hline M20 & 0.3 & 29.33 & 23.04 & $26.45 \%$ \\
\hline M20 & 0.5 & 37.64 & 28.00 & $48.2 \%$ \\
\hline M20 & 0.7 & 30.75 & 28.98 & $8.85 \%$ \\
\hline
\end{tabular}

\begin{tabular}{|l|l|l|l|l|}
\hline Grade of concrete & \% of fibre & Aramid fibre & Steel fibre & \% of increased \\
\hline & & $\begin{array}{l}\text { Stress } \\
\text { (N/SQ.MM) }\end{array}$ & $\begin{array}{l}\text { Stress } \\
\text { (N/SQ.MM) }\end{array}$ & \\
\hline M20 & 0.3 & 29.33 & 23.24 & $30.45 \%$ \\
\hline M20 & 0.5 & 37.64 & 24.31 & $66.65 \%$ \\
\hline M20 & 0.7 & 30.75 & 27.73 & $15.1 \%$ \\
\hline
\end{tabular}

\section{BAR CHART}

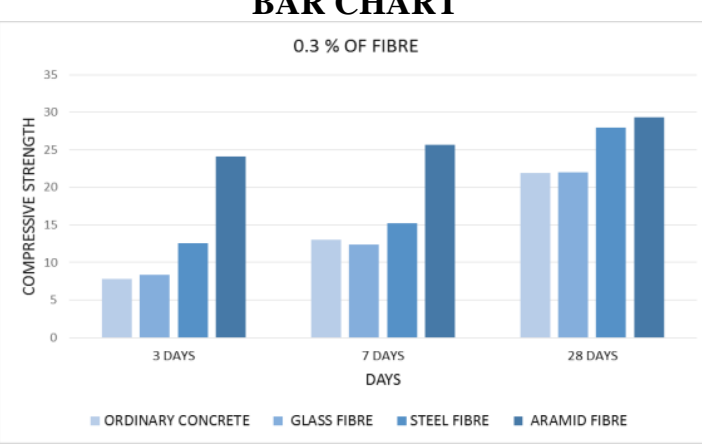




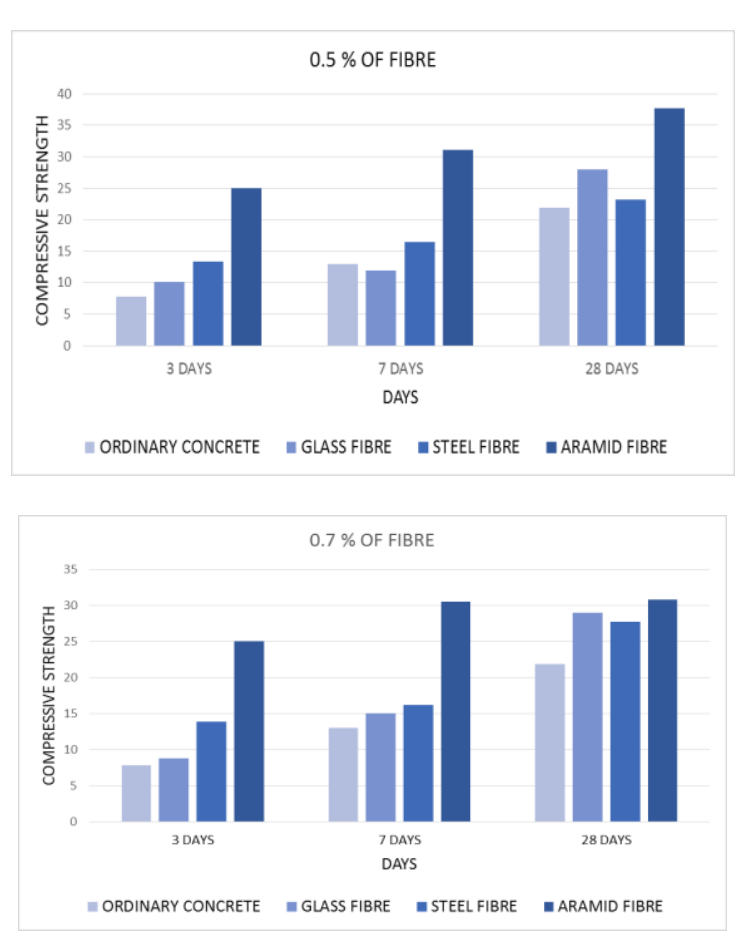

\section{CONCLUSION}

For glass and steel reinforcement, strength of concrete increased with, increased in fibre dosage up to $0.5 \%$ as compared to glass fibre, aramid fibre gives $48 \%$ more compressive strength, whereas when comparing aramid and steel fibre, aramid gives $66 \%$ increased compressive strength.

Aramid reinforced concrete produce massive compressive strength as here, the aramid reinforced concrete is introducing compressive strength as equal to M35 grade in design of M20 grade.

\section{REFERENCES}

[1]. Application and properties of fibre cocncrete

[2]. Author :- Amit Rai and Dr.Y.P Joshi

[3]. Comperssive Behavior Of Steel Fibre Reinforced Concrete

[4]. Author :- R.D.Neves and J.C.O. Fernandes de Almedia

[5]. Experimental Study on Behavior of Steel and Glass Fiber Reinforced Concrete Composites

[6]. Author :- Kavita S Kene, Vikrant S Vairagade and Satish Sathawane

[7]. Experimental Studies on Steel Fiber Reinforced Concrete

[8]. Author:- A N. Shireesha , S. Bala Murugan , G. Nagesh Kumar

[9]. Experimental Study on Properties of Glass Fibre Reinforced Concrete
[10]. Author: - Md.Abid Alam, Imran Ahmad, Fazlur Rehman (Department of Civil Engineering, Integral University). Lucknow

[11]. Effect of fibre addition on concrete strength

[12]. Author :- Shah, Surendra Rangan

[13]. International journal of structural and civil Engineering Research Studies of glass fibre reinforced concrete composite

[14]. Author :- Komal Chawla, August 2013

[15]. International Journal of Emerging Technology and Advanced Engineering Some Studiees On Steel Fibre Reinfirced Concrete

[16]. Author: - Amit Ranal (JANUARY 2013), Adhoc Lecturer, Sarvajanik College of Engineering \& Technology, Surat - 395001, Gujarat, India.

[17]. International Journal of Latest Research in Science and Technology Volume 5, Issue 3: Page No 37-39, May-June 2016

[18]. A Review Study On Use Of Steel Fiber As Reinforcement Material With Concrete

[19]. Author :- Er Gulzar Ahmad1, Er kshipra Kapoor2

[20]. International Journal of Engineering and Science ISSN: 2278-4721, Vol. 1, Issue 12 (December 2012) Performance of Steel Fibre Reinforced Concrete Author :Milind V. Mohod, 1,Assistant Professor, Department of Civil Engineering, P.R.M.I.T.\&R., Badnera.

[21]. Introduction To Steel Fibre Reinforced Concrete On Engineering Performance Of Concrete

[22]. Author :- Vikrant S. Vaingade and Kavita S. kene

[23]. Journal of Engineering Research and Applications Glass Fibre Reinforced Concrete

[24]. Author :- A.Upendra Varma1, A.D. Kumar2 -PG Student (Department of Civil Engineering, V.R. Siddhartha Engineering College, Vijayawada) and Assistant Professor (Department of Civil Engineering, V.R. Siddhartha Engineering College, Vijayawada

[25]. Mechanical Properties of high sterength concrete reinforced with Metalic and NonMetalic fibres

[26]. Author :- Shiv Kumar and Shantanu Manu

[27]. Performance Of Steel Fibre Reinforced Concrete

[28]. Auther: - Milind V. Mohod (Assistant Professor, Department of civil Engineering P.R.M.I. \&R., Bhandara.

[29]. Study On Aramid Fibre and Comparison With Other Composite Materials 
[30]. Author :- Narayan Prasad Sahu Dev Kumar Khande , Gesh Chandra Patel Prakash Kumar Sen,Shailendra Kumar Bohidar

[31]. Strengthening of R.C. Beam using Carbon and Aramid Fibre for its Torsional Behaviour Author :- Sanket Rathi, Sachin Kandekar

[32]. Civil Engineering Department Amrutvahini College of Engineering, Sangamner, India, Dr.

[33]. R.S.Talikoti Civil Engineering Department Late G.N. Sapkal College of Engineering, Nashik,

[34]. Steel Fibre Reinforced concrete

[35]. Author :- Abdul Ghaffar, Amit S. Chavhan , Dr.R.S.Tatwawadi

[36]. SRENGTH PROPERTIES OF GLASS FIBRE CONCRETE

[37]. Author: - Chandramauli K. , Shrinivasa Rao P. , Pannirselvam N. , Seshadri Sekhar T. and Sravana $\mathrm{P}$.

[38]. STEEL FIBRE REINFORCED CONCRETE

[39]. Author :- Nguyen CHANH

[40]. STUDIES OF GLASS FIBRE REINFORCED COCNCRETE COMPOSITES 